\title{
Occurrence of CCR5 Heterozygous 32 bp Deletion in Nepali Ethnic Groups
}

\author{
Nanda Bahadur Singh ${ }^{1,2}$ \\ ${ }^{1}$ Unit of Human Biology and Genetics, Department of Biological Sciences \\ School of Science, University of Tokyo, Tokyo 113-0033, Japan \\ ${ }^{2}$ Address to Correspondence: Central Department of Zoology \\ Tribhuvan University, Kirtipur, Kathmandu, Nepal \\ E-mail: nanda_nepal@yahoo.com
}

\begin{abstract}
The Chemokine (C-C) receptor $5(\mathrm{CCR} 5)$ as one of the small signaling proteins, is a HIV-1 resistant gene. The major boosting to the study of CCR5 gene among ethnic groups in the world is the detection of 32 bp deletion in its heterozygous and homozygous condition which is responsible for relative or absolute resistance to HIV-1 infection. A total of 456 samples belonging to six Nepalese ethnic groups were subjected to genotyping by the use of PCR-RFLP for detecting 32 bp deletion on exon 3 of CCR5 gene. Finally, allele frequencies of 32 bp deletion among Nepalese ethnic groups were calculated by the use of Hardy-Weinberg formula for analysis and interpretation. Chidimar ethnic group, for the first time, showed heterozygous $32 \mathrm{bp}$ deletion at the population level in Asia-pacific region is an excitement in which Chidimar might have conferred resistance against HIV-1 infection in Nepal.
\end{abstract}

Keywords: CCR5 gene, 32 bp deletion, HIV-1 infection, genotypes, ethnic groups.

\section{INTRODUCTION}

Chemokine (C-C) receptor 5 (CCR5), one of small signaling proteins, belongs to $\mathrm{CC}$ type subfamily of chemokines (Samson et al. 1996). CCR5 gene is also alternatively known by CCCKR5, CMKBR5, CKR5 or Chem13 (Samson et al. 1996; Dean et al. 1996). Major attraction towards the CCR5 gene began, when it was identified as a co-receptor for the human immunodeficiency virus-1 (HIV-1) (Deng et al. 1996; Dragic et al. 1996). CCR5 and fusin are two co-receptor promoting the fusion of HIV-1 with the plasma membrane of CD4+ cells. More specifically, CCR5 was responsible for facilitating the entry of macrophage-tropic strains of HIV-1 (Deng et al. 1996). CCR5 was localized to chromosome 3p21 (Liu et al. 1996).

The researches from different perspectives on the CCR5 gene were initiated after identifying its molecular basis (Liu et al. 1996; Samson et al. 1996; Mummidi et al. 1997) for HIV-1 resistance. The genomic structure of CCR5 is rather interesting. It contains 4 exons with only 2 introns. The exons 2 and 3 are joined together without intron and the exon 4 contains the open reading frame (Mummidi et al. 1997; Fig 2a \& 2b).

After detecting the thirty-two base pair deletion $(<32$ or 32 bp deletion) in two independent studies in relation to HIV-1 patients, it was hypothesized that the $32 \mathrm{bp}$ deletions in its heterozygous and homozygous condition may be responsible for relative or absolute resistance to HIV-1 infection (Samson et al. 1996; Liu et al. 1996).
This kind of $32 \mathrm{bp}$ deletion provides a protective mechanism for those individuals who are homozygous confer resistance to HIV-1 infection despite high-risk exposure, whereas those who are heterozygous appear to have slower progression to AIDS following infection. It provided a major boosting to the study of $32 \mathrm{bp}$ deletion among many ethnic groups. A rapid PCR based assay was devised to detect the $32 \mathrm{bp}$ deletion among individuals of major global populations (Martinson et al. 1997). The genotype survey of CCR5-del32 allele across Eurasia gave a clear picture of its frequency cline north-to-south downhill gradient and ethnic specificity (Stephens et al. 1998). It is also reported that the individuals having 32 bp deletions are at reduced risk of developing asthma (Hall et al. 1999). There are no reports on the prevalence of the CCR5 gene among a vast body of Nepalese ethnic groups till now. Therefore, genotyping was performed for the detection of $32 \mathrm{bp}$ deletion among six Nepalese ethnic groups to evaluate its allele frequency.

\section{MATERIALS AND METHODS}

Altogether 456 samples belonging to six Nepalese ethnic groups were subjected to genotyping for detecting 32 bp deletion within the exon 3 of CCR5 gene (Table 1). Different methods were implemented to extract DNA from blood as well as nails samples.

Amplification of genomic DNA was carried out by using two different sets of primers on exon 3 (Figs. 2a \& 2b). The 1 st specific set of primers was used only for PCR 
for detecting $32 \mathrm{bp}$ deletion directly without using the restriction enzyme (Fig. 2b). But the $2^{\text {nd }}$ set of primers was used to amplify the fragment length and then to digest with the restriction enzyme in order to confirm the results obtained by the $1^{\text {st }}$ with that of the $2^{\text {nd }}$ set of primers.

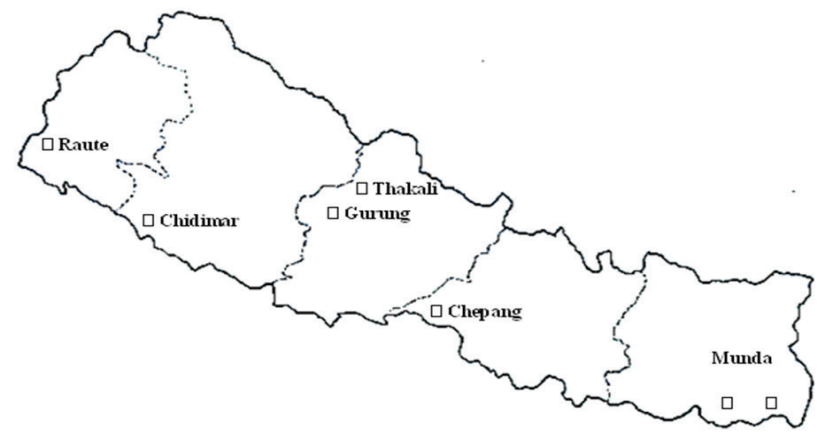

Fig. 1. Map and location of the indigenous populations studied in Nepal

For the $1^{\text {st }}$ specific set of primers, a $182 \mathrm{bp}$ fragment length flanking the deletion site of the CCR5 gene was amplified by PCR using the previously applied (Liu et al. 1996) CCR5-specific forward and reverse primers: SP4.760 (5'-CCTCATTACACCTGCAGCTCT-3') and PM6.942 (5'-CACAGCCCTGTGCTTCTTCTT-3').

For the $2^{\text {nd }}$ set of primers, a $735 \mathrm{bp}$ fragment length of the CCR5 gene was amplified by PCR using the previously applied (Samson et al. 1996) forward and reverse primers: CCR5F (5'-CCTGGCTGTCGTCCATGCTG-3') and CCR5R (5'-CTGATCTAGAGCCATGTGCACAACTC T-3'). PCR was performed in a PCR machine (Program Temp. Control System PC-800, Japan) with the same PCR conditions for both sets of primers. Components of PCR reaction were PCR buffer I (Applied Biosystems,

Japan), $1.65 \mathrm{mM} \quad \mathrm{MgCl}_{2} 0.22 \mathrm{mM}$ each dNTP, $0.2 \mathrm{pM} / \mathrm{ul}$ reverse and forward primer, and $0.05 \mathrm{U} / \mathrm{ul}$ AmpliTaq Gold (Applied Biosystems).

The conditions for the PCRs were an initial denaturation at $95^{\circ} \mathrm{C}$ for $9 \mathrm{~min}, 40$ cycles of $94^{\circ} \mathrm{C}$ for $30 \mathrm{sec}, 62^{\circ}$ for $30 \mathrm{sec}$ and $72^{\circ}$ for $1 \mathrm{~min}$ with additional extension at $72^{\circ} \mathrm{C}$ for $5 \mathrm{~min}$ in the last cycle. The expected PCR products for the $1^{\text {st }}$ specific set of primers were $182 \mathrm{bp}$ and $150 \mathrm{bp}$ fragments in wild and deletion types, respectively (Fig. $3)$. Similarly, the expected PCR products for the $2^{\text {nd }}$ set of primers were $735 \mathrm{bp}$ and $703 \mathrm{bp}$, respectively. But it was difficult to distinguish the big sized (703 bp) mutant band from the wild one (735bp). Therefore, subsequent EcoRI digestion at $37^{\circ} \mathrm{C}$ for overnight cleaved the wild $735 \mathrm{bp}$ into a common band of $332 \mathrm{bp}$ for both alleles and into 403 and $371 \mathrm{bp}$ bands for the wild type and mutant alleles, respectively (Figs. 2a \& 2b). After PCR, the fragments were visualized in $3 \%$ agarose gel followed by staining with ethidium bromide and photos were taken by the printgraph (Bioinstrument Atto, Japan). Results from both the primer sets were matched each other. Finally, frequencies of the CCR5 32 bp deletion among Nepalese ethnic groups were calculated by the use of Hardy-Weinberg formula (Table 1).

\section{RESULTS}

Fig. 3 shows the band pattern in two different primer sets. For the $1^{\text {st }}$ set of primers, a $182 \mathrm{bp}$ and $150 \mathrm{bp}$ fragments could easily be distinguished for wild and $32 \mathrm{bp}$ mutant alleles, respectively (Figs. $2 \mathrm{a} \& 2 \mathrm{~b} \&$ Fig. 3). But for the $2^{\text {nd }}$ set of primers, only the $735 \mathrm{bp}$ fragment could be cleaved into a common band of 332 bp and into 403 bp and $371 \mathrm{bp}$ wild and mutant type alleles, respectively (Fig. 2b). Both results were compatible each other.

Table 1. Distribution of genotypes and frequency of $<32$ allele of the CCR5 gene among six Nepalese indigenous populations

\begin{tabular}{ccccccccc}
\hline & & \multicolumn{3}{c}{ Genotype } & & \multicolumn{2}{c}{$<32$ allele } \\
\cline { 3 - 5 } Population & $\mathrm{n}$ & CCR5/CCR5 & CCR5/<32 & $<32 /<32$ & P value & frequency & \pm & SE \\
\hline Chepang & 72 & 72 & 0 & 0 & - & 0.000 & \pm & 0.000 \\
Chidimar & 35 & 29 & 6 & 0 & $>0.05$ & 0.086 & \pm & 0.033 \\
Gurung & 68 & 68 & 0 & 0 & - & 0.000 & \pm & 0.000 \\
Munda & 88 & 88 & 0 & 0 & - & 0.000 & \pm & 0.000 \\
Raute & 102 & 102 & 0 & 0 & - & 0.000 & \pm & 0.000 \\
Thakali & 91 & 88 & 3 & 0 & $>0.05$ & 0.016 & \pm \\
\hline
\end{tabular}

$n$ is the number individuals subjected to analysis. Genotype distribution was tested for conformity with Hardy-Weinberg equilibrium by means of $\mathrm{x}^{2}$ test.

The most important thing is that the $<32$ allele was found among two out of six ethnic groups genotyped. There was a major difference in frequencies between the Caucasoid and Mongoloid populations. The highest frequencies of the mutated allele were found for the first time among the Caucasoid Chidimar (8.6\%) living in the low land 
Terai close to Indian border. The $2^{\text {nd }}$ highest frequency was found in the Thakali group (1.6\%). The Gurung, the Chepang, the Munda and the Raute did not show $32 \mathrm{bp}$ deletions. The detection of the $32 \mathrm{bp}$ deletion in Thakali individuals supported the possible gene admixture with the Caucasoid during their evolution (Table 1).

(a)

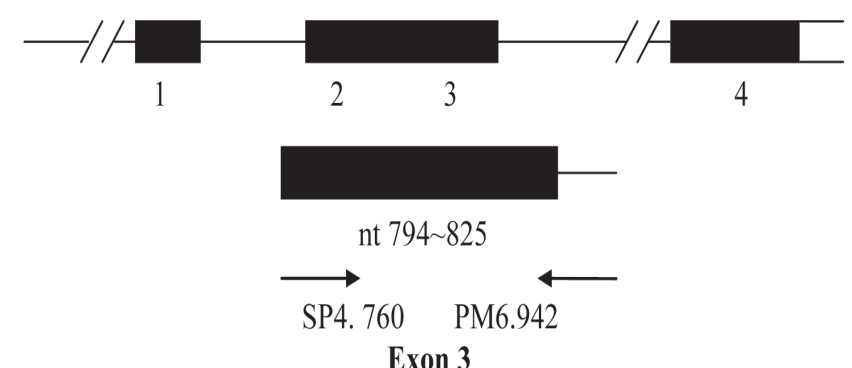

(b)

Fig.2. CCR5 gene analysis: (a) Genomic map of the human CCR5 gene with 4 exons modified from Mummidi et al (1997). (b) Designing a specific primer set flanking the $32 \mathrm{bp}$ deletion site for the PCR.

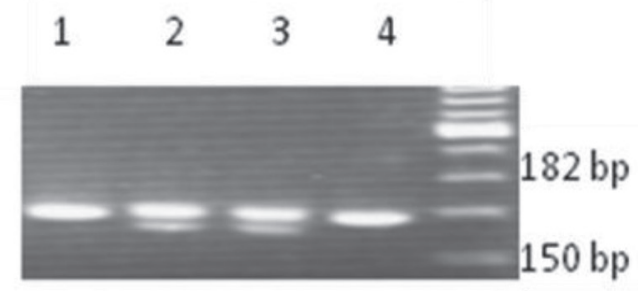

Fig.3. PCR products of the CCR5 gene: CCR5 32 bp deletion in heterozygous state amplified by the onetime PCR with specific primer set. Lanes 2 \& 3: 182bp (wild type); lane $1 \&$ 4: 150 bp (32 bp deletion in heterozygous condition).

\section{DISCUSSION}

For the first time, the present study detected and documented the prevalence of CCR5 $32 \mathrm{bp}$ deletion allele among Nepalese ethnic groups. As in Europe (Lucotte and Mercier, 1998; Lucotte, 2001), a north-tosouth cline was not applicable to Nepalese context due to different ethno-geographical accommodation in the natural environment. Various Mongoloid groups inhabit Northern Nepal where the occurrence of the CCR5 32 bp deletion is very rare in comparison to the Caucasoid. Mid-hill Nepal is co-inhabited by both Mongoloid and Caucasoid groups. The low land Terai is dominated by Caucasoid. But the north south internal migration has changed the whole scenario of population composition.

The frequency of CCR5 32 bp deletion among Nepalese ethnic group ranged from $0 \%$ in the Gurung, the Chepang, the Munda and the Raute, to $1.6 \%$ in the Thakali and to $8.6 \%$ in the Chidimar. The Chidimar ethnic group showed the highest $\%$ of CCR5 $32 \mathrm{bp}$ deletion allele without any European admixture found in Indian Subcontinent. In India alone, allele frequency of $32 \mathrm{bp}$ deletion was detected less than 1\% (Husain et al. 1998). A gene frequency of approximately $10 \%$ was found for the $32 \mathrm{bp}$ deletion in populations of European descent (Martinson et al. 1997). The hypothesis of northern European origin of delta-32 and Viking-mediated dispersal, which was originally proposed by Lucotte and Mercier (1998), was also supported by other similar researches (Novembre et al. 2005). The highest and the lowest frequencies were detected in Finnish/Mordvinian populations (16\%) and Sardinia (4\%) (Libert et al. 1998) respectively. Some results in Slovakian populations do not indicate that a relatively low incidence of HIV-1 infection in Slovakia could be caused by the CCR $5-\Delta 32$ mutation (Takacova et al. 2008). Some findings support previous data showing Delta-32 as a genetic protective factor against HIV-1 infection in Mexican women, as well as in women from other populations (Estrada-Aguirre et al. 2013). Recently a positive correlation has been established between CCR5- $\triangle 32$ and lupus nephritis risk in the Chinese Han ethnic population by playing a role in lupus nephritis susceptibility (Cheng et al. 2014).

This sort of first report of CCR5 32 bp deletion in Nepali Chidimar and Thakali has suggested the further need of carrying out the molecular analysis in order to show whether CCR5 32bp deletion confers the resistance to the HIV-1 infection among many ethnic groups in Nepal or not.

\section{ACKNOWLEDGEMENTS}

I am highly grateful to Professor Takafuni Ishida and his team for giving me an opportunity to carry out the molecular analysis of CCR5 gene among Nepalese ethnic groups at Ishida Laboratory of Unit of Human Biology and Genetics, Department of Biological Sciences, School of Science, University of Tokyo in Japan. I am really gratified to the ethnic leaders and members of Raute, Chidimar, Thakali, Gurung, Chepand and Munda ethnic groups for their cooperation during my field visits.

\section{REFERENCES}

Cheng FJ, Zhou XJ, Zhao YF, Zhao MH, Zhang H. 2014. Chemokine receptor 5 (CCR5) delta 32 polymorphism in lupus nephritis: A large casecontrol study and meta-analysis. Autoimmunity, Apr 10. Electronic publication as supplied by the publisher. 
Dean, M; Carrington, M; Winkler, C; Huttley, GA; Smith, MW; Allikmets, R; Goedert, JJ; Buchbinder, SP; Vittinghoff, E; Gomperts, E; Donfield, S; Vlahov, D; Kaslow, R; Saah, A; Rinaldo, C; Detels, R; Hemophilia Growth and Development Study; Multicenter AIDS Cohort Study; Multicenter Hemophilia Cohort Study; San Francisco City Cohort; ALIVE Study; O’Brien, S. J.1996. Genetic restriction of HIV-1 infection and progression to AIDS by a deletion allele of the CKR 5 structural gene. Science 273: 1856-1861.

Deng, H; Liu, R; Ellmeier, W; Choe, S; Unutmaz, D; Burkhart, M; Di Marzio, P; Marmon, S; Sutton, RE; Hill, CM; Davis, CB; Peiper, SC; Schall, TJ; Littman, DR; Landau, NR.1996. Identification of a major co-receptor for primary isolates of HIV-1. Nature 381: 661-666.

Dragic, T; Litwin, V; Allaway, GP; Martin, SR; Huang, Y; Nagashima, KA; Cayanan, C; Maddon, PJ; Koup, RA; Moore, JP; Paxton, WA. 1996. HIV-1 entry into $\mathrm{CD} 4+$ cells is mediated by the chemokine receptor CC-CKR-5. Nature 381: 667-673.

Estrada-Aguirre JA, Cázarez-Salazar SG, OchoaRamírez LA, Acosta-Cota Sde J, Zamora-Gómez R, Najar-Reyes GM, Villarreal-Escamilla P, Osuna-Ramírez I, Díaz-Camacho SP, SánchezZazueta JG, Ríos-Tostado JJ, Velarde-Félix JS. 2013. Protective effect of CCR5 Delta-32 allele against HIV-1 in Mexican women. Curr HIV Res. Sep; 11 (6):506-510.

Hall, I. P., Wheatley, A., Christie, G., McDougall, C., Hubbard, R., Helms, P.J. 1999. Association of CCR5 delta-32 with reduced risk of asthma. Lancet 354: 1264-1265.

Husain, S; Goila, R; Shahi, S; Banerjea, AC. 1998. First report of a healthy Indian heterozygous for delta-32 mutant of HIV-1 co-receptor-CCR5 gene. Gene 207: 141-147.

Libert, F.; Cochaux, P.; Beckman, G.; Samson, M.; Aksenova, M.; Cao, A.; Czeizel, A.; Claustres, M.; de la Rua, C.; Ferrari, M.; Ferrec, C.; Glover, G.; Grinde, B.; Guran, S.; Kucinskas, V.; Lavinha, J.; Mercier, B.; Ogur, G.; Peltonen, L.; Rosatelli, C.; Schwartz, M.; Spitsyn, V.; Timar, L.; Beckman, L.; Parmentier, M.; Vassart, G. 1998. The deltaccr5 mutation conferring protection against HIV-1 in Caucasian populations has a single and recent origin in northeastern Europe. Hum. Molec. Genet 7: 399-406.
Liu, R; Paxton, WA; Choe, S; Ceradini, D; Martin, SR; Horuk, R; MacDonald, ME; Stuhlmann, H; Koup, RA; Landau, NR. 1996. Homozygous defect in HIV-1 coreceptor accounts for resistance of some multiply-exposed individuals to HIV-1 infection. Cell 86: 367-377.

Lucotte, G; Mercier, G.1998. Distribution of the CCR5 gene 32-bp deletion in Europe. Journal of Acquired Deficiency Syndromes and Human Retrovirology 19: 174-177.

Lucotte, G.2001. Distribution of the CCR5 gene 32-basepair deletion in west Europe. A hypothesis about the possible dispersion of the mutation by the Vikings in historical times. Human immunology 62: 933-936.

Martinson, JJ; Chapman, NH; Rees, DC; Liu, YT; Clegg, JB.1997. Global distribution of the CCR5 gene 32-basepair deletion. Nature Genet. 16: 100-103.

Mummidi, S; Ahuja, SS; McDaniel, BL; Ahuja, SK. 1997. The human CC chemokine receptor 5 (CCR5) gene: multiple transcripts with 5-primeend heterogeneity, dual promoter usage, and evidence for polymorphisms within the regulatory regions and noncoding exons. J. Biol. Chem. 272: 30662-30671.

Novembre, J., Galvani, A. P., Slatkin, M.2005. The geographic spread of the CCR5 delta-32 HIVresistance allele. PLoS Biol. 3: e339.

Samson, M; Labbe, O; Mollereau, C; Vassart, G; Parmentier, M. 1996. Molecular cloning and functional expression of a new human CCchemokine receptor gene. Biochemistry 35: 33623367.

Stephens, JC; Reich, DE; Goldstein, DB; Shin, HD; Smith, MW; Carrington, M; Winkler, C; Huttley, GA; Allikmets, R; Schriml, L; Gerrard, B; Malasky, M; and 27 others.1998). Dating the origin of the CCR5-del32 AIDS-resistance allele by the coalescence of haplotypes. Am. J. Hum. Genet. 62: 1507-1515.

Takácová M, Nogová P, Hábeková M, Staneková. D. 2008. Prevalence of a $32 \mathrm{bp}$ deletion in the gene for human immunodeficiency virus 1 co-receptor CCR5 in Slovak population. Acta Virol 52(4):261264. 